\title{
Relative risk of injury due to alcohol consumption in car and motorcycle drivers
}

\author{
Mahnaz Yadollahi ${ }^{1}$ and Forough Pazhuheian ${ }^{1}$ \\ ${ }^{1}$ Trauma Research Center, Shahid Rajaee Hospital, Shiraz University of Medical Sciences, Shiraz, Islamic Republic of Iran. (Correspondence to: M. \\ Yadollahi: yadollahim@sums.ac.ir).
}

\begin{abstract}
Background: There is strong evidence that a substantial number of fatal as well as nonfatal injuries in road traffic accidents result from alcohol consumption and abuse.

Aims: To examine the relationship between blood alcohol concentration and characteristics of injury in trauma patients admitted to a major teaching hospital.

Methods: This was a cross-sectional investigation of trauma characteristics among 38435 car and motorcycle drivers referred to the South of Iran Trauma Center between October and March 2018. A log-binomial regression model was used to evaluate the relative risk of each covariate on the Injury Severity Score.

Results: There were 253 patients $(7.78 \%$ ) with alcohol consumption. Also, blood alcohol level was positive in $8.66 \%$ and $6.93 \%$ of car and motorcycle drivers, respectively. The ISS in alcohol consumers and nonconsumers was 6.34 (standard deviation; 8.73) and 4.12 (7.78), respectively, which was significantly higher in the alcohol consumers ( $t$ test $=12.96, P<0.001$ ). Therefore, alcohol consumption was a significant factor in increasing the relative risk of injury, which was 2.83 units more than among drivers who had not consumed alcohol.
\end{abstract}

Conclusions: Our findings show that the police and law enforcement agencies have a responsibility to enforce stricter rules to reduce drink driving and the burden of trauma on the healthcare system.

Keywords: drink driving, traffic accident, Injury Severity Score, Islamic Republic of Iran

Citation: Yadollahi M; Pazhuheian F. Relative risk of injury due to alcohol consumption in car and motorcycle drivers. East Mediterr Health J. 2020;26(12):1525-1531. https://doi.org/10.26719/emhj.20.057

Received: 04/06/19; accepted: 22/09/19

Copyright (c) World Health Organization (WHO) 2020. Open Access. Some rights reserved. This work is available under the CC BY-NC-SA 3.0 IGO license (https://creativecommons.org/licenses/by-nc-sa/3.o/igo).

\section{Introduction}

Road traffic accidents (RTAs) are the leading cause of death and disability among people aged $20-50$ years (1). Despite improved hospital care, mortality from RTAs is the second leading public health problem in the Islamic Republic of Iran (2). There is strong evidence that a substantial number of fatal as well as nonfatal injuries results from alcohol consumption and abuse (3); therefore, it can be argued that alcohol consumption is one of the most well-known risk factors for RTAs $(4,5)$. High alcohol consumption was attributed to $14 \%$ of all road traffic injuries and the rate of alcohol consumption in RTAs has been reported to vary from $14 \%$ to $26 \%(4,6)$. It is reported that the chance of an accident after alcohol consumption is 6.1 times higher than without alcohol consumption (7). Among the Iranian population in 2015, the prevalence rate of substance use was $2.65 \%$ in people aged $15-64$ years and the approximate number of addicts was estimated to be 1325000 (8). Despite strict rules and prohibitions on consuming, buying and selling of alcohol in the Islamic Republic of Iran, the prevalence of alcohol consumption among young educated people is still increasing (9). Although studies have found a direct correlation between alcohol and mortality $(10,11)$, the effect of blood alcohol level on Injury Severity Score (ISS) has not been measured when this group is matched with drivers who do not consume alcohol (12).
No specific study has determined the prevalence of alcohol-related injuries in RTAs in the Islamic Republic of Iran where, as a Muslim-majority country, alcohol is illegal. Moreover, no study has reported the consequences of alcohol consumption and other demographic variables on severity of injury in RTAs. The aims of this study were to determine the prevalence of alcohol consumption in car and motorcycle drivers involved in RTAs and to compare the severity of injuries between alcohol consumers and non-consumers. We also compared the prevalence of drink driving in the Islamic Republic of Iran to that in other Muslim-majority countries in the Middle East and countries in which alcohol is legal.

\section{Methods}

This was a retrospective cohort investigation of trauma characteristics among car and motorcycle drivers involved in RTAs who were referred to Shahid Rajaee Trauma Center (Emtiaz) between October and March 2018. We excluded patients aged $<15$ years; patients who were discharged or died within 24 hours; patients dead on arrival at hospital; patients without the data necessary to calculate their trauma score; patients whose Abbreviated Injury Scale (AIS) values were not measurable; patients with unclear type of trauma; and patients with mild injuries such as soft tissue damage and fractures.

Alcohol consumption was determined by measuring 
blood alcohol level in a diagnostic laboratory. ISS was considered as the outcome variable. ISS was based on radiological findings and the International Statistical Classification of Diseases, 10th revision (ICD-10) codes.

Demographic data including age, sex, type of driver, time of admission to hospital, duration of hospitalization, and ISS were studied. Experts calculated severity by referring to patients' medical records, including diagnostic ICD-10 codes, surgical reports, primary triage papers and emergency reports. Each ICD-10 injury code was assigned to one of the 6 ISS body regions. According to the AIS, each patient's injured body regions corresponded to the injured body region with the highest ISS. In this regard, all injuries received an AIS code ranging from 1 (minor injury) to 6 (an injury considered incompatible with life). Patients with multiple injuries were scored by adding the squares of the three highest AIS scores in 3 predetermined body regions. This process provided the ISS which ranged from 1 to 75 . Additionally, because there was no information on alcohol consumption in patients' records, this information was based on the patients' admission code.

Statistical methods such as chi2 test, two independent $\mathrm{t}$ tests, and one-way analysis of variance were used for descriptive comparisons of demographic characteristics and clinical indicators in alcohol and non-alcohol consumers. Binary outcomes in cohort studies are commonly analysed by applying a logistic regression model to the data to obtain odds ratios (ORs) for comparing groups with different sets of characteristics.
Although this is often appropriate, there may be situations in which it is more desirable to estimate a relative risk or risk ratio (RR) instead of OR. With minor modification of the statements for logistic regression, a log-binomial model can be run to obtain the RR instead of the OR. All that needs to be changed is the link function between the covariates and outcome (13). Therefore, a logbinomial regression model was used to evaluate the RR of each covariate in ISS (divided into ISS $\leq 8 \mathrm{vs}$ ISS $>8$ based on distribution of injury severity). A 2 -sided $\mathrm{P}<0.05$ was considered statistically significant. Data were analysed using Stata14 software and figures were prepared using R 3.4.3 for Windows.

This project was approved by the Research Ethics Committee with number of IR.SUMS.REC.1397.420 by Shiraz University of Medical Sciences in Shiraz, Islamic Republic of Iran.

\section{Results}

There were a total of 38435 injured patients, which included $253(7.78 \%)$ who were positive for alcohol consumption. Blood alcohol level was positive in $8.66 \%$ of car and $6.93 \%$ of motorcycle drivers involved in RTAs.

The average age of alcohol users was 26.16 (7.98) years, $95.26 \%$ of whom were male and $4.7 \%$ female (Table 1). The ISS in alcohol users was 6.34 (8.73) and there was a significant difference between the alcohol consumers and nonconsumers. The number of people with ISS $>8$ was greater among alcohol consumers than nonconsumers (26.49\% vs $15.01 \%)$. The highest number of

\begin{tabular}{|c|c|c|c|}
\hline Variables & $\begin{array}{c}\text { Alcohol consumption } \\
\text { (253) }\end{array}$ & $\begin{array}{l}\text { No alcohol consumption } \\
(2998)\end{array}$ & $\mathbf{P}$ \\
\hline Age, mean (SD) & $26.16(7.98)$ years & $33.02(13.85)$ years & $<0.001$ \\
\hline Sex & & & 0.045 \\
\hline Male & $241(95.26)$ & 2749 (91.69) & \\
\hline Female & $12(4.74)$ & $249(8.31)$ & \\
\hline Type of driver & & & 0.066 \\
\hline Car & $139(54.96)$ & $1467(48.93)$ & \\
\hline Motorcycle & $114(45.06)$ & $1531(51.07)$ & \\
\hline Injury severity score, mean (SD) & $6.34(8.73)$ & $4.12(7.78)$ & $<0.001$ \\
\hline $1-4$ & $156(61.66)$ & $2371(79.09)$ & \\
\hline $5^{-8}$ & $30(11.86)$ & $177(5.9)$ & \\
\hline $9-15$ & $39(15.42)$ & $247(8.24)$ & \\
\hline $16-25$ & $17(6.72)$ & $146(4.87)$ & \\
\hline$>25$ & $11(4.35)$ & $57(1.90)$ & \\
\hline Time of accident & & & $<0.001$ \\
\hline 20:00-04:00 & $204(80.63)$ & $1093(36.46)$ & \\
\hline 04:00-12:00 & $19(7.51)$ & $560(18.68)$ & \\
\hline $12: 00-20: 00$ & $30(11.86)$ & $1345(44.86)$ & \\
\hline Injured patients per day, mean (SD) & & & $<0.001$ \\
\hline In holidays & $2.04(0.34)$ & $16.31(0.56)$ & \\
\hline In non-holidays & $0.79(0.07)$ & $11.55(0.12)$ & \\
\hline
\end{tabular}

SD = standard deviation 


\begin{tabular}{|c|c|c|c|c|c|}
\hline \multirow[t]{2}{*}{ Variables } & \multirow[t]{2}{*}{$\mathbf{R R}$} & \multirow[t]{2}{*}{ Z statistic } & \multirow[t]{2}{*}{$\mathbf{P}$} & \multicolumn{2}{|c|}{$95 \%$ CI for $\mathrm{RR}$} \\
\hline & & & & Lower & Upper \\
\hline Age & 1.01 & 2.91 & 0.04 & 1.00 & 1.01 \\
\hline $\begin{array}{l}\text { Sex } \\
\text { (Female to Male) }\end{array}$ & 2.16 & 4.27 & $<0.001$ & 1.51 & 2.09 \\
\hline $\begin{array}{l}\text { Type of driver } \\
\text { (motorcycle driver to car drivers) }\end{array}$ & 0.6 & -6.69 & $<0.001$ & 0.65 & 0.72 \\
\hline Alcohol & 2.83 & -44.06 & $<0.001$ & 1.54 & 2.17 \\
\hline
\end{tabular}

$C I=$ confidence interval; $R R=$ relative risk

accidents (80.63\%) among alcohol consumers occurred between 20:00 and 04:00 hours. The average number of patients injured daily was significantly greater during holidays in comparison to working days for both alcohol consumers and nonconsumers.

A log-binomial regression model was performed to determine the relative risk of covariates on ISS (Table 2). The predictive variables were age, sex, type of driver (motorcycle or car) and alcohol consumption and the independent variable was ISS. Increasing age with control of other variables led to a 0.01 increase in risk of ISS in $>8$ patients. The risk of severe injury was significantly higher in motorcycle compared to car drivers. Alcohol consumption was a significant factor in increasing the relative risk which was 2.83 units more in comparison to that in non-alcohol consumers.

A closer look at the alcohol titer among surviving patients indicates that the severity of injury increased with alcohol consumption and it was higher in motorcycle than car drivers (Figure 1).

Figure 2 shows the percentage of accidents among drinkers in each age group. The percentage of accidents in alcohol users was higher among younger drivers. About $12 \%$ of injured drivers aged $15-20$ years had a positive result for alcohol consumption at the time of the accident. As age increased, the number of accidents also decreased among alcohol users.

\section{Discussion}

The current study evaluated the effect of alcohol consumption on severity of injury in drivers involved in RTAs. The relationship between percentage of alcohol consumption and increased risk of accident was evaluated using log-binomial regression.

The prevalence of alcohol consumption while driving was $7.78 \%$ in our study, which is less than in other studies. The results of a study in US National Trauma Data Bank (2007-2010) indicated that among a total of 88794 motorcycle drivers, $30.9 \%$ showed positive test results for alcohol (14). A study in Virginia, United States of America showed that prevalence of alcohol consumption while driving was about $36.89 \%$ (15). In Australia, blood alcohol was present in $29.1 \%$ of all drivers (16). In a study of RTAs in Turkey, alcohol was detected in the blood of about $54.4 \%$ of cases, although subjects were considered to be positive when alcohol blood concentration exceeded $50 \mathrm{mg} / \mathrm{dl}$ (17). In other studies the prevalence of alcohol in drivers was lower than in our study. A study in the United Arab Emirates found that the prevalence of

\section{Figure 1 ISS stratified by blood alcohol level}

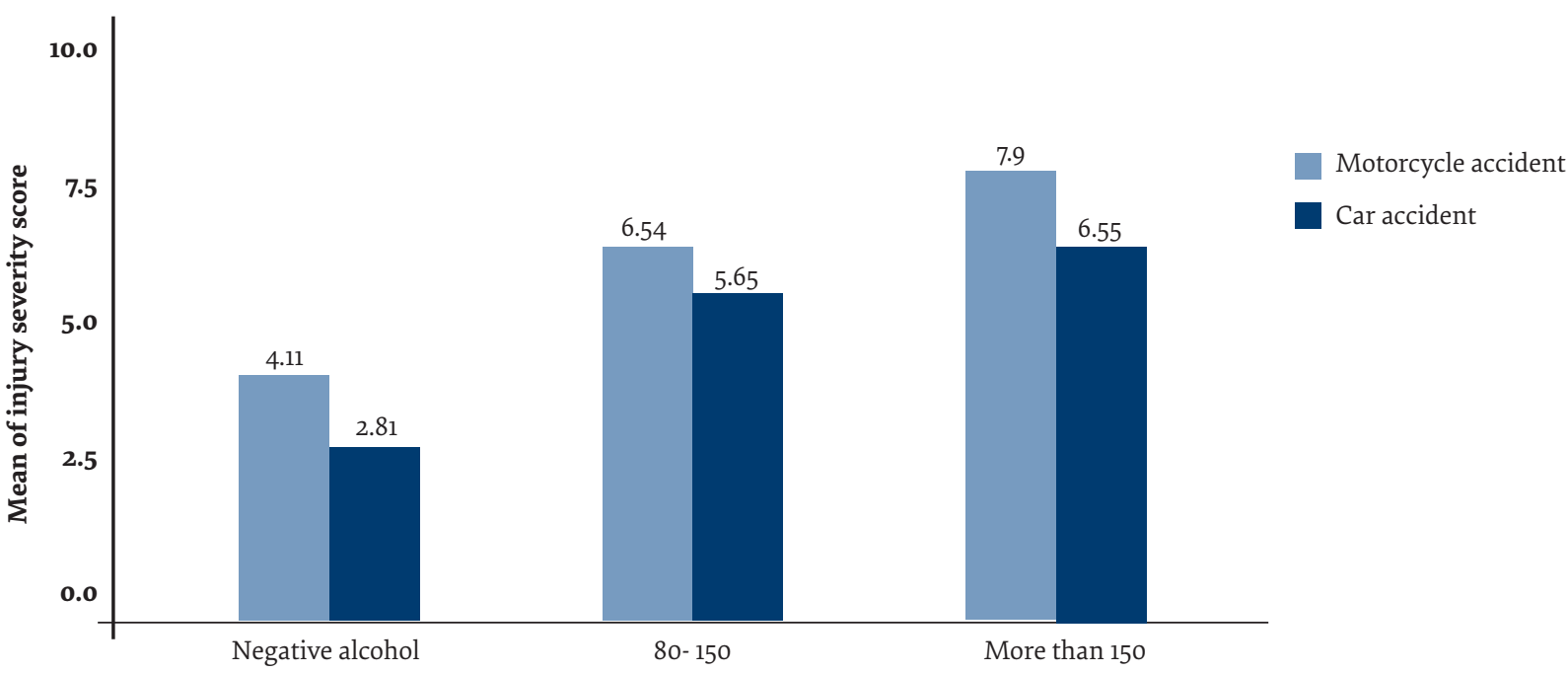


Figure 2 Percentage of accidents among drinkers by age groups

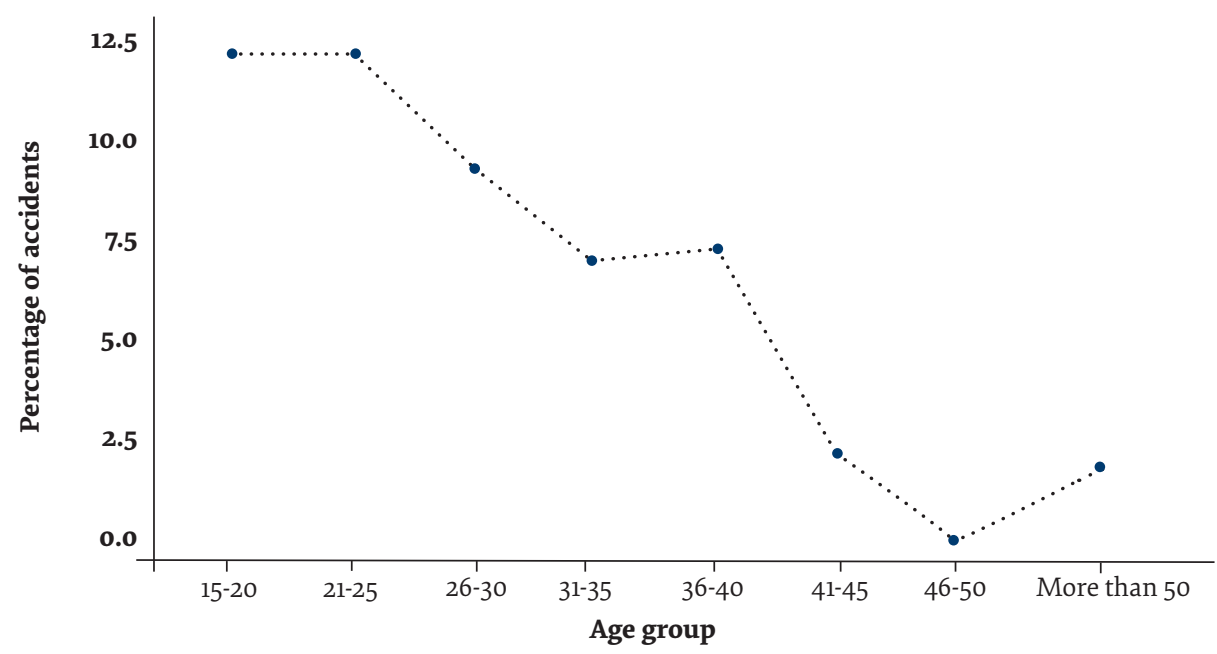

alcohol consumption in car drivers was about 2.2\% (18). Also, prevalence of alcohol among injured drivers was reported as $0.45 \%$ in Norway (19). In a study in Qatar, the prevalence of driving while under the influence of alcohol was estimated as $1.8 \%(20)$. A study in Singapore showed that $2.3-3.0 \%$ of fatal and injury-sustaining RTAs were alcohol related (21). The differences in alcohol consumption patterns in different countries are due to stringent laws as well as religion. Moreover, it should be noted that our study considered blood alcohol $>80 \mathrm{mg} /$ $\mathrm{dl}$ as alcohol consumption. The permissible amount of alcohol in the blood differs between countries; in some it is $100 \mathrm{mg} / \mathrm{dl}$ and in others it is $50 \mathrm{mg} / \mathrm{dl}$.

Our results revealed that consumption of alcohol increased ISS by 2.8 times to $>8$ compared to nonconsumers. Our results are consistent with those of Valdez et al., who showed that blood alcohol level is associated with ISS for specific types of injuries; however, across all types of injuries, there was no significant association between blood alcohol level and ISS (22).

We found that ISS in motorcycle drivers was higher than that in car drivers. This is consistent with the studies of Bolandparvaz et al., who reported injury patterns among trauma patients of different ages and sex in the Islamic Republic of Iran (23), and Yadollahi et al., who conducted an epidemiological study of trauma patients who attended national, cultural and religious events in the Islamic Republic of Iran (24). Both those studies included RTAs and showed that injury in motorcycle drivers was more severe than in car drivers. Our study was the first to evaluate the risk of accidents caused by alcohol consumption in Fars Province. The highest prevalence of alcohol consumption among victims of RTAs occurred in those aged 20-25 years and it seemed that high-risk behaviour such as alcohol consumption decreased with advancing age. As we indicated, ISS was in direct correlation with blood alcohol titre. Our study showed that the percentage of accidents among young drinkers was higher than among older patients, which is consistent with a study of alcohol consumption in Denmark (25).

Alog-binomial regression model was used in this study to analyse injury severity due to alcohol consumption in RTAs, with control of other variables. Hoong et al. have used this model to evaluate occurrence of RTAs at road intersections for several years and have shown that the log-binomial model is more effective than survival models for evaluation of relative risk of injury (26). Our study can pave the way for developing theories about the reasons behind the high incidence of RTAs due to alcohol consumption in holidays. As a result of higher injury severity among alcohol consumers, we recommend that greater supervision is needed regarding high-risk driving behaviour. We also advise law enforcers to implement stricter laws concerning the ban on alcohol consumption.

The limitations of our study include the fact that we were not able to determine the type of body injuries compared to injury severity in different parts of the body. Moreover, data about deaths at the scene as well as prehosital deaths, type of car, speed, seat belt use and drowsy driving were not available. The effect of these varibles as well as opioid substances should be evaluated in future studies for evaluation of competitive risks related to alcohol consumption in occurrence of RTAs.

\section{Conclusion}

Trauma is harmful to patients, imposes a burden on the healthcare system, and is of significant concern to public health. The findings of our study show that the police and law enforcement agencies have a responsibility to arrange preventive laws to reduce the overall prevalence of drink driving and decrease the burden of trauma on the healthcare system.

Funding: This research was supported with grant number of 97-01-38-16888 by Shiraz University of Medical Sciences in Shiraz, Islamic Republic of Iran.

Competing interests: None declared. 


\section{Risque relatif de traumatismes dus à la consommation d'alcool chez les conducteurs de voitures et de motos}

\section{Résumé}

Contexte : Il existe des preuves solides indiquant qu'un nombre important de traumatismes, mortels et non mortels, dans les accidents de la circulation résultent de la consommation et de l'abus d'alcool.

Objectifs : Examiner la relation entre le taux d'alcoolémie et les caractéristiques des blessures chez les patients traumatisés admis dans un grand hôpital universitaire.

Méthodes: Il s'agissait d'une étude transversale des caractéristiques des traumatismes chez 38435 conducteurs de voitures et de motos envoyés au Centre de traumatologie du sud de la République islamique d'Iran entre octobre et mars 2018. Un modèle de régression log-binomial a été utilisé pour évaluer le risque relatif de chaque covariable en utilisant le Score de gravité des traumatismes.

Résultats : 253 patients $(7,78 \%)$ avaient une consommation d'alcool. En outre, le taux d'alcoolémie était positif chez $8,66 \%$ et $6,93 \%$ des conducteurs de voitures et de motos, respectivement. Le Score de gravité des traumatismes chez les consommateurs d'alcool et les non-consommateurs était de 6,34 (écart-type ; 8,73) et 4,12 (7,78), respectivement, ce qui était significativement plus élevé chez les consommateurs d'alcool (test $t=12,96, p<0,001$ ). La consommation d'alcool est donc un facteur important dans l'augmentation du risque relatif de blessure, qui est de 2,83 unités de plus que chez les conducteurs qui n'ont pas consommé d'alcool.

Conclusions : Nos conclusions montrent que la police et les forces de l'ordre ont la responsabilité d'appliquer des règles plus strictes pour réduire la conduite sous l'emprise de l'alcool et le fardeau des traumatismes qui pèsent sur le système de soins de santé.

$$
\text { الدراجات النارية والسيارات للإصابات بسبب تعاطي الكحول }
$$

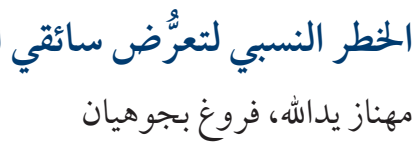

الخلفية: ثَمَّة دلائل قوية على أن عدداً كبيراً من الإصابات المميتة وغير المميتة المرتبطة بحو ادث المرور على الطرق ناجمة عن تعاطي الكحول وإساءة استخدامه. الأهداف: هدفت هذه الدراسة إلى دراسة العلاقة بين تركيز الكحول في الدم وخصائص الإصابة لدى مرضى الإصابات الشديدة الذين أدخلوا إلى

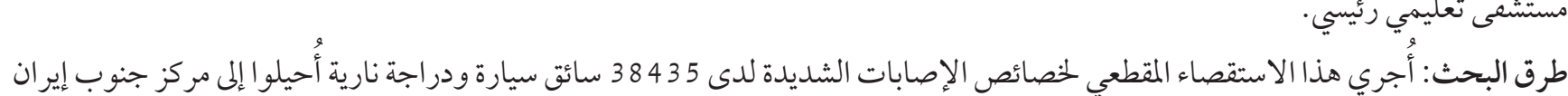

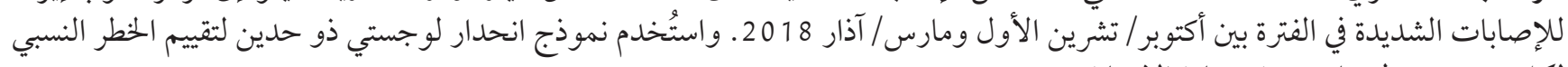
لكل متغير مشترك على درجة وخامة الإصابة.

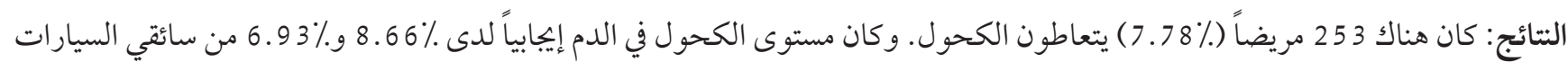

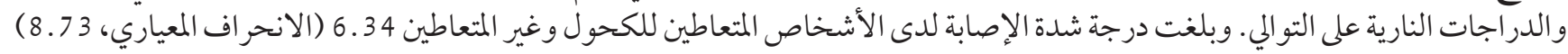

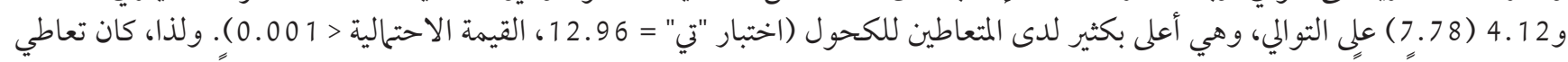

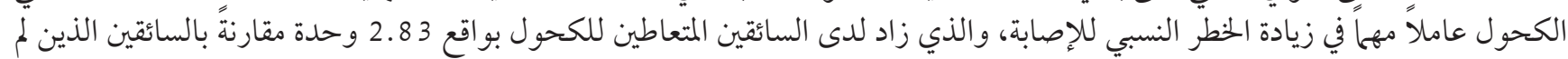
يتعاطو الكحول.

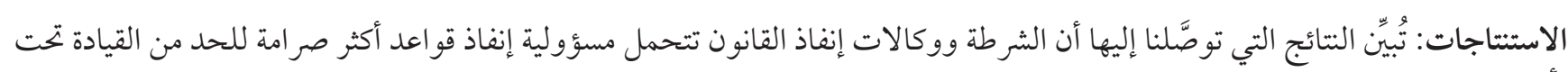

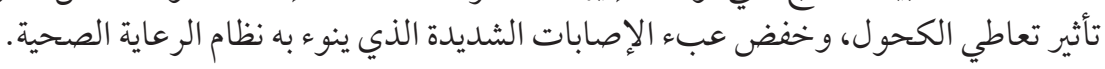




\section{References}

1. Yadollahi M, Ghiassee A, Anvar M, Ghaem H, Farahmand M. Analysis of Shahid Rajaee hospital administrative data on injuries resulting from car accidents in Shiraz, Iran: 2011-2014 data. Chin J Traumatol. 2017 Feb;20(1):27-33. http://dx.doi.org/ 10.1016/j. cjtee.2015.10.006 PMID:28233728

2. Montazeri A. Road-traffic-related mortality in Iran: a descriptive study. Public Health. 2004 Mar;118(2):110-3. http://dx.doi.org/ 10.1016/So033-3506(03)00173-2 PMID:15037040

3. Daeppen JB, Gaume J, Bady P, Yersin B, Calmes JM, Givel JC, et al. Brief alcohol intervention and alcohol assessment do not influence alcohol use in injured patients treated in the emergency department: a randomized controlled clinical trial. Addiction. 2007 Aug;102(8):1224-33. http://dx.doi.org/10.1111/j.1360-0443.2007.01869.x PMID:17565563

4. Borges G, Monteiro M, Cherpitel CJ, Orozco R, Ye Y, Poznyak V, et al. Alcohol and road traffic injuries in Latin America and the Caribbean: a case-crossover study. Alcoholism Clin Exp Res. 2017 Oct;41(10):1731-7. http://dx.doi.org/10.1111/acer.13467 PMID:28905388

5. Osman OT, Abbas AK, Eid HO, Salem MO, Abu-Zidan FM. Alcohol-related road traffic injuries in Al-Ain City, United Arab Emirates. Traffic Inj Prev. 2015;16(1):1-4. http://dx.doi.org/10.1080/15389588.2014.895923 PMID:24617582

6. Odero W. Alcohol-related road traffic injuries in Eldoret, Kenya. East Afr Med J. 1998 Dec;75(12):708-11. PMID:10065211

7. Movig KL, Mathijssen M, Nagel P, Van Egmond T, De Gier JJ, Leufkens H, et al. Psychoactive substance use and the risk of motor vehicle accidents. Accid Anal Prev. 2004 Jul;36(4):631-6. http://dx.doi.org/10.1016/Sooo1-4575(03)00084-8 PMID:15094417

8. Heydarabadi AB, Ramezankhani A, Barekati H, Vejdani M, Shariatinejad K, Panahi R, et al. Prevalence of substance abuse among dormitory students of Shahid Beheshti University of Medical Sciences, Tehran, Iran. International journal of high risk behaviors \& addiction. 2015 Jun 20;4(2):e22350. http://dx.doi.org/ 10.5812/ijhrba.22350v2 PMID:26405679

9. Nasrollahzadeh D, Kamangar F, Aghcheli K, Sotoudeh M, Islami F, Abnet C, et al. Opium, tobacco, and alcohol use in relation to oesophageal squamous cell carcinoma in a high-risk area of Iran. British journal of cancer. 2008 Jun 3;98(11):1857-63. http://dx. doi.org/10.1038/sj.bjc.6604369 PMID:18475303

10. Gururaj G, Uthkarsh PS, Rao GN, Jayaram AN, Panduranganath V. Burden, pattern and outcomes of road traffic injuries in a rural district of India. Int J Inj Contr Saf Promot. 2016;23(1):64-71. http://dx.doi.org/10.1080/17457300.2014.945465 PMID:25109622

11. Global status report on alcohol and health 2018. Geneva: World Health Organization; 2018 (https://www.who.int/substance_ abuse/publications/global_alcohol_report/en/, accessed 11 May 2020).

12. Esser MB, Wadhwaniya S, Gupta S, Tetali S, Gururaj G, Stevens KA, et al. Characteristics associated with alcohol consumption among emergency department patients presenting with road traffic injuries in Hyderabad, India. Injury. 2016 Jan;47(1):160-5. http://dx.doi.org/10.1016/j.injury.2015.07.022 PMID:26260623

13. Agresti A, Kateri M. Categorical data analysis. Springer; 2011.

14. Ahmed N, Greenberg P. Assessing the impact of blood alcohol concentration on the rate of in-hospital mortality following traumatic motor vehicle crash injury: a matched analysis of the National Trauma Data Bank. Injury. 2019 Jan;50(1):33-8. http://dx.doi. org/10.1016/j.injury.2018.09.022 PMID:30245280

15. Beydoun H, Teel A, Crowder C, Khanal S, Lo BM. Past blood alcohol concentration and injury in trauma center: propensity scoring. Journal of emergency medicine. 2014 Oct;47(4):387-94. http://dx.doi.org/10.1016/j.jemermed.2014.06.024 PMID:25161095

16. Drummer OH, Gerostamoulos J, Batziris H, Chu M, Caplehorn JR, Robertson MD, et al. The incidence of drugs in drivers killed in Australian road traffic crashes. Forensic Sci Int. 2003 Jul 8;134(2-3):154-62. http://dx.doi.org/10.1016/s0379-0738(03)00134-8 PMID:12850411

17. Akgür SA, Ertas H, Altntoprak AE, Ozkan M, Kitapcoglu G. Prevalence of alcohol in blood samples from traffic accident cases in Turkey. Am J Forensic Med Pathol. 2011 Jun;32(2):136-9. http://dx.doi.org/10.1097/PAF.obo13e3182186fo7 PMID:21490496

18. Moazen B, Shokoohi M, Noori A, Rahimzadeh S, Saeedi Moghaddam S, Rezaei F, et al. Burden of drug and alcohol use disorders in Iran: findings from the Global Burden of Disease Study 2010. Arch Iran Med. 2015 Aug;18(8):480-5. http://dx.doi.org/015188/ AIM.004 PMID:26265515

19. Gjerde H, Normann PT, Pettersen BS, Assum T, Aldrin M, Johansen U, et al. Prevalence of alcohol and drugs among Norwegian motor vehicle drivers: a roadside survey. Accid Anal Prev. 2008 Sep;40(5):1765-72. http://dx.doi.org/10.1016/j.aap.2008.06.015 PMID:18760106

20. Eid AM. Road traffic accidents in Qatar. The size of the problem. Accid Anal Prev. 1980 Dec;12(4):287-98. https://doi. org/10.1016/0001-4575(80)90006-8

21. Chao TC, Lo D, Bloodworth BC, Tan-Siew W. Drinking and driving in Singapore, 1987 to 1989. Arukoru Kenkyuto Yakubutsu Ison. 1992 Feb;27(1):30-41. PMID:1596242

22. Valdez C, Radomski M, Renne C, Amdur R, Dunne J, Sarani B. Alcohol level and injury severity: is the floppy patient myth true? J Surg Res. 2016;200(2):664-8. http://dx.doi.org/10.1016/j.jss.2015.10.001 PMID:26521676

23. Bolandparvaz S, Yadollahi M, Abbasi HR, Anvar M. Injury patterns among various age and gender groups of trauma patients in southern Iran: a cross-sectional study. Medicine. 2017 Oct;96(41):e7812. http://dx.doi.org/10.1097/MD.0000000000007812 PMID:29019874 
24. Yadollahi M, Gerami M, Shamsedini N. Epidemiologic Study of Trauma Patients Admitted to Shahid Rajaee Hospital of Shiraz, Iran on National, Religious, and Cultural Occasions within 2009-2014. J Health Res Commun. 2017;3(1):38-44. http://jhc.mazums. ac.ir/article-1-183-en.html

25. Simonsen KW, Linnet K, Rasmussen BS. Driving under the influence of alcohol and drugs in the eastern part of Denmark in 2015 and 2016: abuse patterns and trends. Traffic injury prevention. 2018 Jun 4;19(5):468-75. http://dx.doi.org/10.1080/15389588.2018.14 28743 PMID:29370543

26. Chin HC, Quddus MA. Applying the random effect negative binomial model to examine traffic accident occurrence at signalized intersections. Accid Anal Prev. 2003 Mar;35(2):253-9. http://dx.doi.org/10.1016/s0001-4575(02)00003-9 PMID:12504146 